\title{
The Influence Of Climate Leadership, Organizational Behavior And Discipline Work Against The Performance Of Members Of The Police Of The Republic Of Indonesia Sabhara Units Of The Resort City Of Padang
}

\author{
Anton Kusuma Jaya \\ Program Studi Magister Manajemen Sekolah Tinggi Ilmu Ekonomi \\ "Keuangan, Perbankan Dan Pembangunan" Padang \\ anton.kusumajaya74@gmail.com
}

\begin{abstract}
The purpose of this research was: 1) to explain whether there was a Climate of leadership, Organizational Behavior Disciplines Work on performance of Member unit of the police of the Republic of Indonesia Sabhara Resort City of Padang and 2) measure the magnitude of the influence of Climate leadership, Organizational Behavior Disciplines Work on performance of Member unit of the police of the Republic of Indonesia Sabhara Resort City of Padang.

This research was conducted in February-March 2016 in Sabhara units of the police force of the Republic Indonesia's resort city of Padang.

The sample used in this study as many as 32 respondents using a sampling of saturated. As for the independent variable of climate leadership, Organizational Behavior Disciplines work, whereas the variable dependennya is the performance of members of the police. This research is explanatory research.

The method of data collection is the kuestioner. Data analysis techniques using Descriptive Analysis and Inferensial Analysis.

To know how the variables are independent of the dependent variable are partial, used test $t$. Whereas to know the influence of the variables are independent of the dependent variables simultaneously, use the test $F$. Assumptions used in the test of validity is if $R$-female $>R$-table item is declared valid. $R$-count shown in the table above, from individual items suggests that $R$-female $>R$-table so that the items are declared valid.

Based on a test of the validity of the instrument of climate leadership, Organizational Behavior and discipline Work against Performance known to all items stated valid and reliability test results show that the instruments have a high reliability and meets the criteria of a good instrument requirements, i.e., valid and reliability.

Free Leadership Behavior variables $(X 1)$ effect significantly to performance $(Y)$, Organizational Climate (X 2) a significant effect on performance, variable $(Y)$ Discipline work (X 3) a significant effect on performance (Y). Hypothesis (H1) until the Union (H3) third.
\end{abstract}

Keywords: Organizational Climate, Leadership Behavior Discipline of work and Performance 


\section{Pendahuluan}

Faktor sumber daya manusia, sangat menentukan keberhasilan suatu organisasi yang dikelola. Demikian penting faktor sumber daya manusia sehingga didalam strategi dan rencana organisasi, investasi di bidang sumber daya manusia mutlak dilakukan.Untuk mewujudkan tujuan yang diinginkan tersebut, maka salah satunya yaitu dengan meningkatkan kemampuan sumber daya manusia. Karena sumber daya manusia merupakan faktor kunci untuk meningkatkan kinerja suatu organisasi. Banyak faktor-faktor yang dapat digunakan untuk meningkatkan kinerja karyawan, antara lain melalui kepemimpinan, kedisiplinan, motivasi dan peningkatan terhadap kemampuan kerja karyawan.

Keberhasilan seorang pemimpin sangat di tentukan oleh kepemimpinannya, meliputi kemampuan dan interaksi sesama pemimpin, bawahan dan atasan. Kepemimpinan seseorang akan sangat mempengaruhi cara pengambilan keputusan dan kinerja dari suatu organisasi yang dipimpinnya. Setiap pemimpin akan memperlihatkan kepemimpinan kedalam situasi tertentu yang dapat dimunculkan lewat ucapan, sikap dan tingkah laku yang dirasakan oleh dirinya sendiri maupun oleh orang lain.

Menciptakan sebuah iklim organisasi yang mampu membawa para anggotanya untuk meningkatkan kinerja dalam rangka pencapaian tujuan organisasi bukanlah suatu hal yang mudah. Hal ini disebabkan karena pada dasarnya manusia memiliki karakteristik tingkah laku yang berbeda sesuai dengan tingkat kebutuhannya.

Apabila terdapat perbedaan atau kesenjangan antara persepsi anggota dengan persepsi pimpinan mengenai iklim yang dirasakan dan yang diharapkan, maka ini akan memungkinkan terciptanya ketidakpuasan kerja dari anggota, sehingga dapat menimbulkan penyalahgunaan hakdan kewajiban yang akhirnya mengakibatkan tujuan organisasi tidak dapat dipenuhi secara optimal.

Kinerja karyawan merupakan gambaran mengenai tingkat pencapaian pelaksanaan kegiatan/pekerjaan yang dicapai seseorang atau karyawan untuk mencapai tujuan organisasi dalam periode waktu tertentu.Kinerja karyawan merupakan faktor yang sangat penting bagi suatu organisasi. Hal ini dikarenakan kinerja karyawan sebagai penentu keberhasilan serta kelangsungan hidup organisasi. Oleh karena itu, pencapaian tujuan organisasi sepenuhnya tergantung pada faktor sumber daya manusia yang dapat memberikan kinerja yang tinggi bagi organisasi.

Polri dalam mencapai tujuan organisasinya harus didukung oleh sumber daya manusia serta adanya seorang pemimpin yang reformis dan peduli terhadap perubahan dan dapat memberikan peran penting di dalam jalannya roda organisasi. Sesuai dengan perannya, pemimpin sebagai penunjuk arah dan tujuan di masa depan (direct setter), agen perubahan (agent of change), negosiator (spokesperson), dan sebagai pembina (coach) dalam menggerakkan seluruh komponen atau sumber daya organisasinya untuk mencapai tujuan. Oleh karena itu, seorang pemimpin harus mampu mengarahkan motivasi dengan menciptakan kondisi (iklim) organisasi melalui pembentukan iklim organisasi sehingga para anggota merasa terpacu untuk bekerja lebih keras agar kinerja yang dicapai juga tinggi. Salah satu elemen yang bernilai penting dalam sistem organisasi selain iklim organisasi adalah kepemimpinan (leadership).

Demikian juga dengan iklim organisasi yang ada di dalam suatu organisasi memiliki karakteristik yang berbeda-beda dengan organisasi lainnya. Sebagaimana yang dijelaskan oleh Newstrom dalam (Matondang, 2008) 
bahwa setiap organisasi mempunyai iklim yang berbeda-beda dan masing-masing menunjukkan karakteristik kekhususan suatu organisasi.

Formula yang tepat untuk menemukan tipe prilaku kepemimpinan di lingkungan organisasi kepolisian diharapkan dapat memberikan masukan dan meningkatkan kinerja dan prestasi kerja di organisasi kepolisian. Kunarto menyatakan bahwa di mungkinkan kepemimpinan di Polri lebih cocok dengan model transformasional. (Kunarto, 1997; 155).

Iklim organisasi merupakan sesuatu yang sulit untuk didefmisikan atau diukur secara tepat karena iklim hanya dapat disimpulkan dari keluasannya dan observasi dari yang dikatakan, dilukis dan dilakukan oleh anggota organisasi. Menurut Schein dalam (Wibowo, 2010) iklim adalah suatu pola asumsi dasar yang ditemukan dan dikembangkan oleh suatu kelompok tertentu karena mempelajari dan menguasai masalah adaptasi eksternal dan integrasi internal, yang telah bekerja dengan cukup baik untuk dipertimbangkan secara layak dan karena itu diajarkan pada anggota baru sebagai cara yang dipersepsikan, berpikir dan dirasakan dengan benar dalam hubungan dengan masalah tersebut.

Berdasarkan latar belakang penelitian di atas maka penulis akan memfokuskan masalah penelitian tesis pada prestasi kerja anggota dan khususnya menguji Pengaruh Perilaku Kepemimpinan, Iklim Organisasi dan Disiplin Kerja Terhadap Kinerja Anggota Satuan Sabhara Kepolisian Republik Indonesia Resor Kota Padang. Pertanyaan penelitian dalam penelitian ini adalah Bagaimana Pengaruh Perilaku Kepemimpinan, Iklim Organisasi dan Disiplin Kerja terhadap Kinerja Anggota Satuan Sabhara Kepolisian Republik Indonesia Resor Kota Padang?
Dalam tujuan dalam penelitian ini penulis beracuan dari rumusan masalah yang telah dijelaskan di atas, yaitu Untuk menguji Pengaruh Perilaku Kepemimpinan, Iklim Organisasi dan Disiplin Kerja terhadap Kinerja Anggota Satuan Sabhara Kepolisian Republik Indonesia Resor Kota Padang.

Manfaat praktis penelitian ini adalah untuk memberi masukan kepada Kepolisian Republik Indonesia Resor Kota Padang tentang Pengaruh Perilaku Kepemimpinan, Iklim Organisasi dan Disiplin Kerja terhadap Kinerja anggota kepolisian di Satuan Sabhara Kepolisian Republik Indonesia Resor Kota Padang sehingga diharapkan prilaku kepemimpinan, iklim organisasi dan disiplin kerja dapat meningkatkan kinerja anggota kepolisian, dan pada akhirnya tujuan organisasi dapat tercapai secara optimal.

Manfaat secara teoritis diharapkan dalam penulisan tesis ini dapat memberikan sumbangan pemikiran dalam mengembangkan ilmu pengetahuan yang berkaitan dengan Kajian Ilmu Kepolisian. Selain itu, hasil penelitian ini juga dapat digunakan sebagai acuan ataupun sumber informasi kepustakaan bagi para peneliti lain yang akan melakukan penelitian berkaitan dengan masalah prilaku kepemimpinan, iklim organisasi, disiplin kerja dan kinerja anggota di Satuan Sabhara Kepolisian Republik Indonesia Resor Kota Padang.

\section{Tinjauan Pustaka}

\section{Kinerja}

Kinerja merupakan perwujudan dan hasil kerja atau karya dari seseorang anggota organisasi yang pada gilirannya akan menentukan keselurahan dari keberhasilan organisasi. Sehingga dapat pula dikatakan bahwa tercapai atau tidaknya tujuan organisasi terutama ditentukan oleh kinerja anggota organisasi,baik secara kualitas maupun kuantitas.

Rivai (2009) mendefinisikan 
kinerja merupakan suatu fungsi dari motivasi dan kemampun untuk menyelesaikan tugas atau pekerjaan. Seseorang sepatutnya memiliki derajat kesediaan dan tingkat kemampuan tertentu. Kesediaan dan keterampilan seseorang tidaklah cukup efektif untuk mengerjakan sesuatu tanpa pemahaman yang jelas tentang apa yang akan dikerjakan dan bagaimana mengerjakannya. Kinerja merupakan perilaku nyata setiap seseorang sebagai prestasi kerja dalam organisasi. Kinerja karyawan merupakan suatu hal yang sangat penting dalam upaya organisasi dalam mencapai tujuannya.

\section{Perilaku Kepemimpinan}

Kepemimpinan memiliki berbagai macam pengertian yang terkadang sering sulit didefmisikan, sehingga banyak orang dan ahli mencoba memperkenalkan defmisinya sesuai versi masing-masing. Salah satu di antaranya adalah Robert Schuller dalam (Salusu, 2005) yang mengatakan bahwa kepemimpinan adalah suatu kekuatan yang menggerakkan perjuangan atau kegiatan anda menuju sukses. Schuller yakin bahwa dalam diri setiap orang terdapat potensi kepemimpinan, tetapi sayang banyak yang tidak menyadari.

Kepemimpinan adalah suatu proses dalam mempengaruhi orang lain agar mau atau tidak melakukan sesuatu yang diinginkan. Ada juga yang mengatakan bahwa kepemimpinan (leadership) adalah hubungan interaksi antara pengikut (follower) dan pimpinan dalam mencapai tujuan bersama.(Matondang, 2008). Pendapat lain juga disampaikan oleh Glenn (1992) dalam (Salusu, 2005) mengatakan bahwa lebih cenderung untuk melihat kepemimpinan dari segi kualitas sehingga kepemimpinan yang berkualitas ialah kemampuan atau seni memimpin orang biasa untuk mencapai hasil-hasil yang luar biasa.

Kepemimpinan juga merupakan penggerak bagi sumber daya-sumber daya dan alat-alat yang dimiliki oleh organisasi. Defmisi kepemimpinan, menurut Terry (Kartono 2003 : 38) Kepemimpinan adalah aktivitas mempengaruhi orangorang agar mereka suka berusaha mencapai tujuan-tujuan kelompok. Hasil tinjauan penulis-penulis lain mengungkapkan bahwa para penulis manajemen sepakat bahwa kepemimpinan adalah proses mempengaruhi aktivitas seseorang atau sekelompok orang untuk mencapai tujuan dalam situasi tertentu. Menurut Ordway Teod dalam bukunya "The Art OfLeadership" (Kartono 2003 : 38).

\section{Iklim organisasi}

Iklim organisasi jika dikaitkan dengan Iklim dalam organisasi merupakan suasana dalam suatu organisasi yang diciptakan oleh pola hubungan antar pribadi ( interpersonal relationship) yang berlaku. Pola hubungnan ini bersumber dari hubungan antar guru dengan guru lainnya atau meungkin hubungan antar peminpin dengan guru. Pola hubungan antara guru dengan pemimpin membentuk sesuatu jenis kepemimpinan dalam melaksanakan fungsi-fungsi kepemimpinannya.

Iklim orgaisasi yang kondusif sangat dibutuhkan untuk menumbuhkan dorongan dalam diri tersebut untuk bekerja lebih bersemangat. Ini berarti bahwa iklim organusasi sekolah berpengaruh terhadap tinggi rendahnya motivasi para guru. Hal ini sesuai dengan ungkapan Dirjen Dikti (Buku IIC, 1983:45), yang menyebutkan bahwa, "Iklim organisasi sangat mempengaruhi motivasi dan produktivitas para anggotanya untuk berpartisipasi, ada pula iklim yang justru memadamkan motivasi untuk berprestasi”.

Iklim organisasi yang dimaksudkan dalam penelitian ini adalah tingkat kebutuhan komunikasi diantara orang-orang yang terlibat dalam pekerjaan tingkat keterbentukan 
merupakan salah satu kategori iklim organisasi yang dikembangkan oleh Hoy dan Miskel, (2001:190) yang disebutnya sebagai Open Climate.

Berdasarkan definisi tersebut, maka dapat disimpulkan bahwa Iklim organisasi adalah sejumlah persepsi orang-orang terhadap lingkungan di mana ia bekerja. Lebih jauh persepsi tersebut mempengaruhi perilaku mereka dalam bekerja. Lebih jauh persepsi tersebut mempengaruhi perilaku mereka dalam bekerja. Banyak dimensi Iklim organisasi seperti yang dikemukakan oleh Hoy dan Miskel, (2001:190-198), yaitu: suportive, directive, restrictive, collegial, intimate, dan disengaged.

\section{Disiplin kerja}

Disiplin berasal dari kata "discipline" yang berati latihan atau pendidikan kesopanan dan kerohanian serta pengembangan tabiat. Dilain pihak Wahyudi (2002) mengemukakan bahwa disiplin adalah keadaan yang menyebabkan atau memberikan dorongan kepada pegawai untuk berbuat dan melakukan segala kegiatan sesuai normanorma atau aturan-aturan yang telah ditetapkan. Disiplin adalah sikap yang menggambarkan kepatuhan pada suatu aturan atau ketentuan yang berlaku. Disiplin merupakan suatu tuntutan bagi berlangsungnya kehidupan bersama yang teratur, tertib yang merupakan syarat mutlak bagi berlangsunya suatu kemajuan dan perkembangan. Disiplin tidak akan timbul dengan sendirinya, disiplin harus dididik dan ditanamkan sejak dini.

Disiplin kerja pada dasarnya adalah suatu kondisi yang tercipta dan terbentuk melalui proses serangkaian prilaku yang menunjukan nilai-nilai ketaatan, kepatuhan, kesetiaan, keteraturan dan/atau ketertiban. Karena itu disiplin melekat pada diri seseorang sehingga sikap dan perbuatan yang dilakukan tidak lagi dirasakan sebagai beban. Bahkan bila tidak berdisiplin ia merasa bersalah dan merasa ada kekurangan pada dirinya. Sikap dan prilaku ini terbentuk dari kebiasaan, proses pendidikan dalam keluarga, pengalaman, lingkungan dan keteladanan.

Disiplin kerja mempunyai tiga aspek, yaitu (1) sikap mental (mental attitude), yang merupakan sikap taat dan tertib sebagai hasil latihan, pengendalian pikian dan watak, (2) pemahaman yang baik mengenai sistem aturan prilaku, norma, kriteria dan standar, sehingga menumbuhkan kesadaran sebagai syarat mutlak untuk mencapai keberhasilan, dan (3) sikap dan kelakuan yang menunjukan kesungguhan hati, untuk menaati segala hal secara cermat dan tertib.

Dari indikator di atas dapat disimpulkan bahwa disiplin seorang karyawan harus mempunyai rasa tanggung jawab terhadap pekerjaan, menghargai waktu dan memiliki rasa solidaritas yang tinggi serta menjaga nama baik organisasi/instansi.

\section{Tinjauan penelitian terdahulu}

Pengaruh Perilaku Kepemimpinan Terhadap Kinerja Anggota Kepolisian Republik Indonesia Resor Kota Padang Sri Elviani 087017034/Akt Sekolah Pascasarjana Universitas Sumatera Utara Medan 2010 Pengaruh Motivasi Kerja, Gaya Kepemimpinan, Komunikasi Dan Budaya Organisasi Terhadap Kinerja Manajerial Dengan Kepuasan Kerja Pegawai Sebagai Variabel Intervening (Studi Kasus Pada Universitas Islam Sumatera Utara), Hasil penelitian menunjukkan bahwa secara simultan motivasi (prestasi kerja, pengaruh, pengendalian, ketergantungan, perluasan dan afiliasi), gaya kepemimpinan (gaya partisipatif, gaya pengasuh, gaya otoriter, gaya birokrasi, gaya berorientasi pada tugas), komunikasi (komunikasi administrasi ke bawah dan 
komunikasi administrasi ke atas) serta budaya organisasi (profesionalisme, jarak dari manajemen, percaya pada rekan kerja, keteraturan, permusuhan dan integrasi) tidak berpengaruh terhadap kinerja manajerial dan secara parsial motivasi (prestasi kerja, pengaruh, pengendalian, ketergantungan, perluasan dan afiliasi), gaya kepemimpinan (gaya partisipatif, gaya pengasuh, gaya otoriter, gaya birokrasi, gaya berorientasi pada tugas), komunikasi (komunikasi administrasi ke bawah dan komunikasi administrasi ke atas) serta budaya organisasi (profesionalisme, jarak dari manajemen, percaya pada rekan kerja, keteraturan, permusuhan dan integrasi) tidak berpengaruh terhadap kinerja manajerial, tetapi komunikasi administrasi ke atas dan jarak dari manajemen yang memiliki pengaruh terhadap kinerja manajerial.

Nicko Achmad Pradityo1, Rodhiyah2 \& Saryadi3, Pengaruh Kepemimpinan dan Iklim Organisasi terhadap Kinerja karyawan Pt. Telkom Indonesia Semarang, Penelitian ini dilakukan untuk mengetahui pengaruh kepemimpinan dan iklim organisasi terhadap kinerja karyawan pada PT Telkom Indonesia Tbk Semarang. Hasil dari penelitian ini menunjukkan bahwa kepemimpinan berpengaruh positif dan signifikan terhadap kinerja karyawan sebesar 37\%. Iklim organisasi juga berpengaruh positif dan signifikan terhadap kinerja karyawan sebesar 47,4\%. Kepemimpinan dan iklim organisasi berpengaruh positif dan signifikan terhadap kinerja karyawan sebesar 74,8\%.
Miswan, STIA Bandung, Pengaruh Perilaku Kepemimpinan, Iklim Organisasi Dan Motivasi Kerja Terhadap Kinerja Dosen Pegawai Negeri Sipil Pada Universitas Swasta Di Kota Bandung (Studi Pada Jurusan/Program Studi di Lingkungan Universitas Swasta SeKota Bandung) Hasil penelitian menunjukkan kepemimpinan berpengaruh positif dan signifikan terhadap kinerja dosen PNS. Iklim organisasi berpengaruh positif tapi tidak signifikan, sedangkan motivasi kerja dosen berpengaruh positif dan signifikan terhadap kinerja dosen PNS pada universitas swasta Kota Bandung. Kesimpulan dari penelitian ini bahwa perilaku kepemimpinan, iklim organisasi dan motivasi kerja merupakan faktor-faktor strategis untuk mewujudkan kinerja dosen PNS yang profesional bermutu. Sementara saran yang diajukan yaitu manakala ketua jurusan ingin mewujudkan kinerja dosen yang profesional maka ketua jurusan hendaknya menentukan model yang tepat mengenai perilaku kepemimpinan, iklim organisasi, dan motivasi kerja.

$\mathrm{H} 1$ = Terdapat Pengaruh Perilaku Kepemimpinan Terhadap Kinerja Anggota Satuan Sabhara Kepolisian Republik Indonesia Resor Kota Padang

Pengaruh Iklim Organisasi Terhadap Kinerja Anggota Satuan Sabhara Kepolisian Republik Indonesia Resor Kota Padang Kadjatmiko (2005)

Pengaruh Kepemimpinan, Iklim Organisasi, dan Organisasi Pembelajaran terhadap Perilaku Organisasi, Studi kasus pada Delapan Kabupaten dan Kota di 
Indonesia. Menyimpulkan bahwa Perilaku organisasi pemda kabupaten dan kota yang diteliti ditandai dengan penguatan ciri perilaku birokrasi profesional Bentuk kegiatan yang didasarkan pada hubungan formal dan informal; Sifat kegiatan yang umum karena diikat oleh visi dan misi yang sama untuk memberikan pelayanan publik; Pelaksanaan fungsi dan kegiatan sebagai satu kesatuan sistem yang terkoordinasi; Sifat pertanggungjawaban yang jelas untuk kepentingan pelayanan publik;

(2014) $\begin{array}{rr}\text { Ananta Ardhi } & \text { Raharja } \\ \text { Universitas } & \text { Dian }\end{array}$

Nuswantoro Semarang, Pengaruh Pendidikan Dan Pelatihan Berbasis Kompetensi (Competence Base Education And Training ) Dan Motivasi Kerja Terhadap Kinerja Petugas Satuan Polisi Pamong Praja Kota Semarang. Hasil penelitian menunjukkan terdapat pengaruh pendidikan terhadap kinerja Satpol PP Kota Semarang dengan nilai $\mathrm{t}$ hitung pendidikan sebesar $16,030>\mathrm{t}$ tabel $(1,662)$ dan nilai signifikansi sebesar $0,000<0,05$. Terdapat pengaruh pelatihan terhadap kinerja Satpol PP Kota Semarangdengan nilai $t$ hitung pelayanan sebesar $18,161>\mathrm{t}$ tabel $(1,662)$ dan nilai signifikansi sebesar $0,000<0,05$. Terdapat pengaruh motivasi terhadap kinerja Satpol PP Kota Semarang dengan nilai $\mathrm{t}$ hitung motivasi sebesar $19,150>\mathrm{t}$ tabel $(1,662)$ dan nilai signifikansi sebesar $0,000<0,05$. Terdapat pengaruh pendidikan, pelatihan dan motivasi terhadap kinerja Satpol PP Kota Semarang dengan nilai $F$ hitung sebesar $256,964>\mathrm{F}$ tabel $(2,71)$ dan signifikansi Fsebesar 0,000 $<0,05$. Adapun saran yang dapat dikemukakan yaitu kinerja anggota Satpol PP kota Semarang sudah baik terhadap pelatihan, disiplin kerja , dan motivasi . Namun, untuk standar kerja perlu lebih disosialisasikan lagi kepada anggota Satpol PP kota Semarang agar anggota benar-benar memahami peraturan-peraturan kerja di institusi dan meminimalisir terjadinya kesalahan dalam bekerja. Pencapaian target dari institusi oleh anggota juga perlu ditingkatkan kembali, agar anggota dalam bekerja selalu mencapai target yang telah ditetapkan institusi. Dengan tercapainya halhal tersebut akan dapat meningkatkan

kinerjaanggotaSatpol PP kota Semarang. Kata Kunci : Pendidikan, Pelatihan, Motivasi, Kinerja.

H2 = Terdapat Pengaruh Iklim Organisasi Terhadap Kinerja Anggota Satuan Sabhara Kepolisian Republik Indonesia Resor Kota Padang.

\section{Pengaruh Disiplin Kerja Terhadap Kinerja Anggota Satuan Sabhara Kepolisian Republik Indonesia Resor Kota Padang}

Nurul Laili 100211100067

Pengaruh Disiplin kerja dan Fasilitas Kerja Terhadap Kinerja Pegawai Satuan Polisi Pamong Praja Kabupaten Sampang. Dibimbing oleh Dr. Muh Alkirom Wildan SE, Msi dan Helmi Buyung Aulia Safrizal, ST., MMT Tujuan penelitian ini adalah untuk mengetahui pengaruh antara disiplin kerja terhadap kinerja pegawai dan untuk mengetahui pengaruh fasilitas kerja terhadap kinerja pegawai Satuan Polisi Pamong Praja. Sampel penelitian ini berjumlah 40 responden. Uji 
kuesioner yang digunakan adalah uji validitas dan uji reliabilitas, Uji $\mathrm{t}$ dan koefisien determinasi. Hasil penelitian ini menyatakan bahwa berdasarkan uji t, variabel disiplin kerja (X1) dan fasilitas kerja (X2) berpengaruh positif signifikan terhadap kinerja (Y) pegawai Satuan Polisi Pamong Praja. Dua variabel tersebut, disiplin kerja variabel mempunyai pengaruh yang positif signifikan terhadap kinerja dan variabel disiplin kerja mempunyai pengaruh yang positif signifikan terhadap kinerja pegawai Satuan Polisi Pamong Praja Kabupaten Sampang. Kata kunci : Disiplin Kerja, Fasilitas Kerja, Kinerja.

Heny Sidanti, Program Studi Stie Dharma Iswara Madiun "Pengaruh Lingkungan Kerja, Disiplin Kerja Dan Motivasi Kerja Terhadap Kinerja Pegawai Negeri Sipil Di Sekretariat DPRD Kabupaten Madiun". Dalam penelitian ini menggunakan dua jenis data yaitu data primer dan sekunder, sedangkan metode penelitian melibatkan dua variabel: variabel (kinerja karyawan) independen, dan variabel dependen (lingkungan kerja, disiplin kerja, motivasi kerja). Jenis penelitian adalah eksperimental desain. Sampel PNS DPRD Kabupaten Madiun. Ukuran populasi diambil sebagai sampel 49, sampling penelitian menggunakan Sampling jenuh (Sensus) yaitu respondennya adalah seluruh karyawan yang ada. Analisis menggunakan uji asumsi klasik dan analisis regresi linier berganda. Studi ini menyimpulkan: lingkungan kerja, disiplin kerja, motivasi untuk bekerja sama dan dampaknya secara bersamaan memiliki pengaruh positif dan signifikan terhadap kinerja PNS
DPRD Kabupaten Madiun, Ini terbukti dari hasil perhitungan SPSS yang t hitung nya lebih besar dari $t$ tabel. Kata kunci: lingkungan, Disiplin, Motivasi. Trihastuti (2006) Pengaruh Prilaku kepemimpinan dan Iklim Organisasi Terhadap Learning Organization (studi kasus pada Badan Pembinaan Hukum Nasional Departemen Hukum dan HAM RI) menyimpulkan bahwa terdapat hubungan yang kuat dan positif antara prilaku kepemimpinan dan iklim organisasi dengan learning organization. Temuan penelitian ini bermakna bahwa learning organization yang sudah berjalan dengan baik di BPHN lebih banyak dipengaruhi oleh adanya potensipotensi prilaku kepemimpinan tidak hanya pada level tertinggi tetapi juga pada semua level organisasi tetapi dan sebaliknya iklim organisasi tidak cukup kondusif untuk mendorong learning organization.

$\begin{array}{lr}\text { Rokhman dan } & \text { Harsono } \\ \text { (2002) Pengaruh } & \text { Prilaku } \\ \text { kepemimpinan } & \text { Terhadap }\end{array}$
Kepemimpinan Transaksional Pada Komitmen Organisasi Dan Kepuasan Bawahan menyimpulkan bahwa hasil regresi menunjukkan ada add-on effect positif dan signifikan sebesar 19,3\%. Faktorfaktor prilaku kepemimpinan mampu memberikan penjelasan tambahan variansi dalam kepuasan bawahan sebesar 19,7\% lebih dari yang dapat dijelaskan oleh faktorfaktor kepemimpinan. Dengan karakteristik penghargaan terhadap bawahan dan merangsang bawahan untuk lebih kreatif dan mengembangkan kemampuannya sebagai sarana aktualisasi diri sehingga menimbulkan kepuasan diri bawahan, maka hal ini sangat 
berpengaruh terhadap kepuasan bawahan terhadap prilaku kepemimpinan.

H3 = Terdapat Pengaruh Disiplin Kerja Terhadap Kinerja Anggota Satuan Sabhara Kepolisian Republik Indonesia Resor Kota Padang.

\section{Metode Penelitian \\ Jenis Penelitian / Objek Penelitian}

Jenis Data dan Variable Data, Data yang dikumpulkan dalam penelitian ini bersifat kwalitatif dan kwantitatif, sebagai data primer yang dihimpun dalam menggunakan metode questioner (angket) dilaksanakan pada Bulan Desember 2015 terhadap pegawai anggota Satuan Sabhara Kepolisian Republik Indonesia Resor Kota Padang.

\section{Populasi Dan Sampel}

Menurut Arikunto (2002) populasi adalah seluruh data yang menjadi perhatian kita dalam suatu ruang lingkup dan waktu yang kitatentukan. Jadi populasi berhubungan dengan data, bukan manusianya. Kalau setiap manusia memberikan suatu data, maka banyaknya atau ukuran populasi akan sama dengan banyaknya manusia. Populasi adalah keseluruhan subjek penelitian, sedangkan menurut Sugiyono (2011) pengertian populasi adalah wilayah generalisasi yang terdiri atas objek/subjek yang mempunyai kualitas dan karakteristik tertentu yang ditetapkan oleh peneliti untuk dipelajari dan kemudian ditarik kesimpulannya. Populasi dalam penelitian ini adalah polisi anggota Satuan Sabhara Polresta Padang dengan jumlah anggota 32 orang.

Pengambilan sampel dilakukan dengan cara stratified proportional random sampling berdasarkan tingkat jabatan struktural. Hal ini akan menghasilkan sampel sesuai dengan proporsi dari setiap kelompok strata populasi. Dalam penelitian ini digunakan metode sensus dimana jumlah sampel sama dengan jumlah populasi yaitu 32 orang.

\section{Jenis dan sumber data}

Penelitian ini menggunakan data yang diperoleh melalui responden, dimana responden akan memberikan respon verbal dan atau respon tertulis sebagai tanggapan atas pernyataan yang diberikan. Adapun jenis data yang digunakan dalam penelitian ini adalah:

1. Data Primer, adalah data mengenai pendapat responden tentang kompetensi dan kinerja yang diperoleh secara langsung dari responden dengan memberikan tanggapan atas pernyataan kuesioner. Dalam penelitian ini penulis mengawali dengan melakukan uji validitas dan reliabilitas terhadap 32 responden yang terdiri dari pegawai anggota kepolisian bidang operasional dan pembinaan di Kepolisian Resor Kota Padang, yang terbagi secara rata dengan menggunakan teknik probability sampling yakni teknik pengambilan sampel yang memberikan peluang sama bagi setiap unsur (anggota) populasi untuk dipilih menjadi sampel.

2. Data Sekunder, adalah data yang diperoleh secara tidak langsung melalui perantara (diperoleh dan dicatat oleh pihak lain). Dalam penelitian ini, data sekunder hanya mendukung pengumpulan data awal sebagai output penelitian.

\section{Penyusunan Skala Dan Indeks}

Penskalaan adalah penempatan nilai / angka pada suatu Continuum atau garis lurus, sedangkan ukuran yang digunakan adalah daftar pertanyaan kuesioner dan data yang diperoleh berupa jawaban responden terhadap pertanyaan yang diajukan ( Supranto,1997). Skala yang dipergunakan dalam penelitian ini adalah skala yang disebut sebagai skala likert. Skala likert merupakan sejumlah pertanyaan yang berkaitan dengan konsep / indikator yang diukur.Untuk itu masing - masing 
variable disediakan masing - masing pertanyaan. Pertanyaan - pertanyaan tersebut diberikan kepada responden untuk diberikan jawaban dengan memilih antara beberapa kategori jawaban yang sudah disiapkan. Dalam penelitian ini penulis menyediakan 5 kategori jawaban ( Skala Likert Lima ) yang disediakan untuk setiap pertanyaan. Pada jawaban tersebut diberi nilai 5,4,3,2, dan 1 untuk masing - masing jawaban pertanyaan dengan kategori sangat setuju, setuju, ragu - ragu, tidak setuju, dan sangat tidak setuju.

\section{Teknik Pengumpulan Data}

Pengumpulan data ini dilakukan dengan teknik survey lapangan. Survai lapangan dimaksudkan untuk mendistribusikan kuesioner yang berisi pertanyaan kepada responden, yang berupa kueisioner yang telah terukur dengan sejumlah pilihan jawaban terhadap pengaruh prilaku kepemimpinan, iklim organisasi dan disiplin kerja terhadap kinerja bidang operasional dan pembinaan di Satuan Sabhara Kepolisian Republik Indonesia Resor Kota Padang.

Hal yang merupakan bahan adalah hal - hal mengenai Prilaku kepemimpinan, Iklim Organisasi dan Disiplin Kerja terhadap Kinerja anggota kepolisian bidang operasional dan pembinaan di Satuan Sabhara Kepolisian Republik Indonesia Resor Kota Padang.

Selain itu juga untuk memperoleh data - data tentang kebijakan yang selama ini mempengaruhi prestasi kerja anggota kepolisian bidang operasional dan pembinaan di Satuan Sabhara Kepolisian Republik Indonesia Resor Kota Padang.

Penulis mengharapkan dengan penyebaran kuesioner ini mendapat data data primer yang bersifat kwantitatif dan informatif yang tepat dan benar tentang pengaruh prilaku kepemimpinan dan iklim organisasi meningkatkan Kinerja anggota Satuan Sabhara Kepolisian
Republik Indonesia Resor Kota Padang melalui Kuesioner disebarkan setelah melakukan wawancara.

Teknik kepustakaan sebagai sumber informasi yang terkait dengan penelitian. Study ini dilakukan untuk memperoleh data atau informasi yang diperlukan yang mempunyai keterkaitan dengan masalah yang diteliti, sehingga dapat dipergunakan sebagai dasar teoritis dalam pembahasan penelitian ini.

\section{Defenisi Operasional dan metode pengukuran variabel}

Terdapat 3 variabel yang termasuk dalam penelitian ini, yaitu independent variable (variabel bebas) yaitu variabel yang mempengaruhi atau menjadi penyebab berubahnya dependent variabel (variabel terikat), dalam penelitian ini adalah :

Kinerja $(Y)$ adalah variabel terikat, Kinerja merupakan perwujudan dan hasil kerja atau karya dari seseorang anggota organisasi yang pada gilirannya akan menentukan keselurahan dari keberhasilan organisasi. Sehingga dapat pula dikatakan bahwa tercapai atau tidaknya tujuan organisasi terutama ditentukan oleh kinerja anggota organisasi, baik secara kualitas maupun kuantitas.

Prilaku kepemimpinan ( X1) variable bebas pertama, gaya kepemimpinan merupakan karakteristik kepribadian, bukan perilaku. Perilaku kepemimpinan dari individu yang sama akan berbeda dari situasi ke situasi, semantara struktur kebutuhan yang mendorong perilaku itu bisa konstan (Fiedler dalam Hoy dan Miskel, 1987).

Iklim Organisasi ( X2) variable bebas kedua iklim organisasi adalah lingkungan manusia dimana para guru melakukan pekerjaan mereka (Davis \& Newstrom, 1996:21) atau serangkaian sifat iklim yang dinilai langsung atau tidak langsung oleh guru yang dianggap menjadi kekuatan utama dalam mempengaruhi prilaku guru (Gibson, 
Ivancevih \& Donneily, 2003:107). Yang dimaksud dengan lingkungan manusia adalah kepemimpinan, motifasi, komunikasi, interaksi pengaruh, pengambilan keputusan, penyusunan tujuan dan pengadilan (Davis \& Newstion). Dengan demikian dapat disimpulkan iklim organisasi adalah kualitas serangkaian sifat iklim, yang dinilai langsung atau tidak langsung oleh pimpinan.

Disiplin Kerja ( X3 ) variable bebas ketiga Disiplin kerja pada dasarnya adalah suatu kondisi yang tercipta dan terbentuk melalui proses serangkaian prilaku yang menunjukan nilai-nilai ketaatan, kepatuhan, kesetiaan, keteraturan dan/atau ketertiban. Karena itu disiplin melekat pada diri seseorang sehingga sikap dan perbuatan yang dilakukan tidak lagi dirasakan sebagai beban. Bahkan bila tidak berdisiplin ia merasa bersalah dan merasa ada kekurangan pada dirinya. Sikap dan prilaku ini terbentuk dari kebiasaan, proses pendidikan dalam keluarga, pengalaman, lingkungan dan keteladanan. Berdasarkan uraian diatas maka penulis menggunakan skala Likert dengan ukuran sebagai berikut: $5=$ sangat setuju, $4=$ setuju, 3 = kurang setuju, 2 = tidak setuju, 1 = sangat tidak setuju. Dan jawabanjawaban responden adalah berskala dan mempunyai gradasi (skala Likert) yang sifatnya positif.

\section{Pengujian instrumen penelitian \\ Uji Validitas Instrumen}

Pengujian validitas instrumen dilakukan dengan dua cara yaitu :

1). Uji coba lapangan

Uji coba lapangan merupakan uji validitas yang paling sederhana. Pengujian dilakukan terhadap anggota yang ada, mereka memiliki karakteristik yang sama dalam tanggung jawab mencapai target pekerjaan dan pelaksanaan tugas yang telah ditetapkan.
2).Uji validitas butir item untuk mengtahui validitas instrument penelitian digunakan analisa item yaitu mengkorelasikan skor tiap butir dengan program SPSS.

Suatu skala pengukuran disebut valid bila ia melakukan apa yang seharusnya dilakukan dan mengukur apa yang seharusnya diukur (Kuncoro, 2003; Sekaran, 2003). Untuk mengetahui apakah pertanyaan-pertanyaan valid atau tidak, maka digunakan bivariate correlation yaitu mengkorelasikan masing-masing item pertanyaan terhadap total item pertanyaan (Ghozali, 2005). Apabila item pertanyaan berkorelasi signifikan dengan total item pertanyaan maka item tersebut dinyatakan valid, dan sebaliknya. Digunakan Coreected Total to item Total minimal 0.30 (Sekaran, 2003)

\section{Uji Reliabilitas}

Menurut Sekaran (2006: 318) reliability is the consistency and stability of the measuring instrument. Pengertian tersebut dapat diartikan bahwa reliabilitas merupakan konsistensi dan stabilitas dari pengukuran instrumen. Dengan demikian, reliabilitas mencakup dua hal utama yaitu stabilitas ukuran dan konsistensi internal ukuran. Untuk mengetahui reliabilitas variabel prilaku kepemimpinan (X1), Iklim Organisasi ( X.2), digunakan Cronbach's alpha minimal 0.70 (Sekaran, 2003).

\section{Teknik Analisa Data}

Analisis Deskriptif

Untuk menginterpretasikan data empirik hasil penelitian melalui penggunaan table distribusi frekuensi, persentase, nilai rerata (mean), median,nilai maksimum dan nilai minimum dari masing-masing indicator. Analisis ini tidak menarik suatu kesimpulan, namun hanya mendeskripsikan data apa adanya berdasarkan tanggapan responden terhadap item-item pertanyaan yang berkaitan dengan variable penelitian ini. Model penelitian dibentuk untuk menguji 
pengaruh antara variable independen dengan variable dependen melalui variable moderator, kemudian menguji variable independent bersama-sama melalui variable moderator terhadap varabel dependen.

\section{Uji Assumsi Klasik \\ Uji Multikolonieritas}

Uji multikolonieritas bertujuan untuk menguji apakah model regresi ditemukan adanya korelasi antar variabel bebas (independent variable). Model regresi yang baik seharusnya tidak terjadi korelasi di antara variabel bebas. Jika variabel bebas saling berkorelasi, maka variabel-variabel tersebut tidak ortogonal. Variabel ortogonal adalah variabel bebas yang nilai korelasi antar sesama variabel bebas sama dengan nol (Ghozali, 2007). Adapun cara untuk mendeteksi ada atau tidaknya multikolonieritas di dalam model regresi melalui nilai tolerence dan variance inflation factor (VIF). Kedua ukuran ini menunjukkan setiap variabel bebas manakah yang dijelaskan oleh variabel bebas lainnya. Dalam pengertian sederhana setiap variabel bebas menjadi variabel terikat dan diregres terhadap variabel bebas lainnya. Nilai cut-off yang umum dipakai untuk menunjukkan adanya multikolonieritas adalah nilai tolerence $<0,10$ atau sama dengan nilai VIF $>10$.

\section{Heteroskedastisitas}

Uji Heteroskedastisitas bertujuan menguji apakah dalam model regresi terjadi ketidaksamaan varian dari residual satu pengamatan ke pengamatan yang lain. Jika varian dari residual satu pengamatan ke pengamatan lain tetap, maka disebut homoskedastisitas dan jika berbeda disebut heteroskedastisitas. Model regresi yang baik adalah yang homoskedastisitas atau tidak terjadi heteroskedastisitas. Untuk mendeteksi ada atau tidaknya heteroskedastisitas dapat dilakukan dengan melihat Garfik Plott (Scatter plot). Jika tidak terdapat pola yang jelas, seperti titik menyebar di atas dan dibawah angka 0 (nol) pada sumbu Y, maka tidak terdapat heteroskedastisitas

\section{Uji Normalitas}

Uji normalitas bertujuan untuk menguji apakah dalam model regresi, variabel pengganggu atau residual memiliki distribusi normal. Seperti diketahui bahwa uji $t$ dan $F$ mengasumsikan bahwa nilai residual mengikuti distribusi normal. Kalau asumsi ini dilanggar maka uji statistik menjadi tidak valid untuk jumlah sampel kecil (Ghozali, 2007). Menurut Ghozali, 2007 untuk mendeteksi uji normalitas dapat dilakukan melalui Analisa grafik. Analisa grafik ini dapat digunakan untuk menentukan normalitas dengan melihat grafik histogram yang membandingkan antara data observasi dengan distribusi yang mendekati distribusi normal.

\section{Uji Linearitas}

Uji linearitas digunakan untuk melihat apakah spesifikasi model yang digunakan sudah benar atau tidak. Untuk menentukan apakah fungsi persamaan regresi yang digunakan berbentuk liner, maka dapat dilihat dari P-P Plot. Apabila titik-titik terdistribusi mengikuti garis linear, maka model regresi dapat dinyatakan linier. Dalam penelitian ini, untuk uji lineritas dipergunakan Grafik PP Plot.

\section{Analisis Korelasi}

Analisa korelasi adalah suatu teknik statistik yang digunakan untuk mengukur keeratan hubungan antara dua variabel (Widyono, 1999 :51). Analisa ini dapat dilakukan melalui korelais bivariate (bivariate correlation) dengan menggunakan person's correlation SPSS.

\section{Analisis regresi linear berganda bertingkat}

Pengujian Hipotesis dilakukan untuk mengetahui apakah hipotesis yang telah dirumuskan dapat Diterima atau Ditolak. Pengujian hipotesis secara statistic dapat dilakukan dengan uji 
signifikan $\mathrm{F}$ - test (test of significance ). Uji signifikan atau tidaknya masing masing variable bebas dalam mempengaruhi variable tidak bebas digunakan uji $-\mathrm{t}$ atau $\mathrm{t}$ - test dan $\mathrm{F}$ - test dengan bantuan program SPSS.

\section{Koefisien determinan ( Uji R )}

Uji $R$ adalah perbandingan antara variasi $\mathrm{Y}$ yang dijelaskan oleh $\mathrm{x} 1$ dan $\mathrm{x} 2$ secara bersama-sama dibanding dengan variasi total $\mathrm{Y}$. Jika selain $\mathrm{x} 1$ dan $\mathrm{x} 2$ semua variabel di luar model yang diwadahi dalam $\mathrm{E}$ dimasukkan ke dalam model, maka nilai $\mathrm{R}^{2}$ akan bernilai 1. Ini berarti seluruh variasi Y dapat dijelaskan oleh variabel penjelas yang dimasukkan ke dalam model. Contoh Jika variabel dalam model hanya menjelaskan 0,4 maka berarti sebesar 0,6 ditentukan oleh variabel di luar model, nilai diperoleh sebesar $\mathrm{R}^{2}=0,4$. Tidak ada ukuran yang pasti berapa besarnya $\mathrm{R}^{2}$ untuk mengatakan bahwa suatu pilihan variabel sudah tepat. Jika $\mathrm{R}^{2}$ semakin besar atau mendekati 1, maka model makin tepat. Untuk data survai yang berarti bersifat cross section data yang diperoleh dari banyak responden pada waktu yang sama, maka nilai $R^{2}=0,2$ atau 0,3 sudah cukup baik. Semakin besar n (ukuran sampel) maka nilai $\mathrm{R}^{2}$ cenderung makin kecil. Sebaliknya dalam data runtun waktu (time series) dimana peneliti mengamati hubungan dari beberapa variabel pada satu unit analisis (organisasi atau negara) pada beberapa tahun maka $\mathrm{R}^{2}$ akan cenderunng besar. Hal ini disebabkan variasi data yang relatif kecil pada data runtun waktu yang terdiri dari satu unit analisis saja. Contoh jika nilai $\mathrm{R}^{2}=0,4$, menunjukkan pemilihan variabel $\mathrm{x} 1$ dan $\mathrm{x} 2$ dalam (cross section data) menjelaskan variasi kinerja sebesar 40 persen, sisanya 80 persen ditentukan oleh variabel-variabel lain di luar model. Dua variabel penjelas yang dipilih oleh peneliti sudah dapat menjelaskan variasi variabel Y pada sampel yang besar. Dapat diterima jika uji $\mathrm{F}$ menunjukkan nilai yang besar atau signifikan, keputusan untuk menerima model harus dilihat bersama antara besarnya nilai $\mathrm{F}$ dan $\mathrm{R}^{2}$.

\section{Uji Model ( Uji F dan Uji t )}

Untuk mengetahui kebenaran koefisien jalur dilakukan pengujian hipotesis dengan uji $\mathrm{F}$ (pengujian secara keseluruhan) dan uji t (pengujian secara individu atau parsial).

Uji F

$$
F=\frac{(n-k-1) \sum_{i=1}^{k} P y x: R y x i}{k\left(1-\sum_{i=1}^{k} P y x i R y x i\right.}
$$

Setelah diperoleh nilai $F$ hitung selanjutnya dibandingkan dengan $\mathrm{F}$ tabel.

Jika $\mathrm{F}$ hitung $>\mathrm{F}$ tabel, maka $\mathrm{H}_{0}$ di tolak.

\section{Uji t}

$$
t_{i}=\frac{P y x i}{\sqrt{\frac{\left(1-R^{2} y x 1-X k\right)\left(C i i \sum_{h=1}^{n} X^{2} i h\right.}{n-k-1}}}: 1=1,2, \text { dan3 }
$$

Setelah diperoleh nilai $t$ hitung selanjutnya dibandingkan dengan nilai $\mathrm{t}$ tabel, jika $\mathrm{t}$ hitung $>\mathrm{t}$ tabel maka koefisien jalurnya signifikan. Pengolahan data statistik tersebut di atas dilakukan dengan bantuan program SPSS.

\section{Uji Hipotesis}

\section{Analisa Regresi Berganda}

Analisa regresi Sederhana adalah suatu teknik statistik yang digunakan untuk mengetahui seberapa besar pengaruh beberapa variabel bebas terhadap variabel terikat (Kuncoro, 2003). Model persamaan regresi berganda dinyatakan sebagai berikut : Untuk menguji Hipotesis Pengaruh Independen variabel $\mathrm{X} 1, \mathrm{X} 2$ dan $\mathrm{X} 3$ terhadap dependen variabel (Y) Kinerja digunakan rumus analisa regresi berganda : 


$$
\begin{aligned}
\mathbf{Y}= & \mathbf{a}+\mathbf{b}_{\mathbf{1}} \mathbf{X}_{\mathbf{1}}+\mathbf{b}_{\mathbf{2}} \mathbf{X}_{\mathbf{2}}+\mathbf{b}_{\mathbf{3}} \\
\mathbf{X}_{\mathbf{3}} & \text { dimana: } \\
\mathrm{Y}= & \text { Kinerja anggota Satuan } \\
& \text { Sabhara Kepolisian } \\
& \text { Resor Kota Padang } \\
\mathrm{X}_{1}= & \text { Prilaku kepemimpinan } \\
\mathrm{X}_{2}= & \text { Iklim Organisasi } \\
\mathrm{X}_{\cdot 3}= & \text { Disiplin Kerja }
\end{aligned}
$$

$\mathrm{a}=$ Konstanta

$\mathrm{b}_{1}, \mathrm{~b}_{2}, \mathrm{~b}_{3}=$ Koefesien regresi $\mathrm{X} 1, \mathrm{X} 2$ dan $\mathrm{X} 3$

\section{Hasil Penelitian Dan Pembahasan Uji Validitas}

Nilai $r$ tabel pada tingkat signifikasi $5 \%$ dengan jumlah responden (n) 32 adalah 0,296 sehingga instrument dinyatakan valid.

\section{Uji reliabilitas}

Hasilnya nilai Cronbach's Alpha lebih besar dari $r$ tabel yaitu 0,581 (x1), 0,687 (x2), 0,559 (x3 dan 0,553 (y) > 0,296 . Dengan demikian dapat disimpulkan bahwa kuesioner atau angket tersebut Reliabel

\section{Hasil Uji Statistik \\ Uji Asumsi Klasik}

Sebelum dilakukan analisis, terlebih dahulu dilakukan pengujian persyaratan analisis, yaitu pengujian terhadap normalitas data dan homogenitas data. Uji normalitas data digunakan untuk melihat penyebaran data yaitu apakah data yang diperoleh berdistribusi normal atau tidak, sedangkan homogenitas untuk melihat apakah data yang diperoleh memiliki varian yang sama atau tidak. Uji normalitas dilakukan dengan uji Kolmogorov-Smirnov.

Suatu model regresi dikatakan linier harus melaui uji asumsi klasik yang terdiri dari uji multikolonieritas, uji heteroskedastisitas, uji normalitas, dan uji linearitas (Ghozali, 2007). Berikut ini akan dilakukan uji asumsi klasik terhadap model regresi sebagai berikut:

\section{Uji Normalitas}

Uji normalitas dilakukan dengan

uji Kolmogorov Smirnov sebagai berikut :

1) Jika nilai Sig atau signifikan atau nilai probabilitas $(\mathrm{P})<0,05 \quad$ (taraf kepercayaan 95\%), distribusi adalah tidak normal

2) Jika nilai Sig atau signifikan atau nilai probabilitas $(\mathrm{P})>0,05 \quad$ (taraf kepercayaan 95\%), distribusi adalah normal

Secara matematis, pada uji normalitas dengan uji kolmogorov smirnov kita membandingkan nilai $\mathrm{F}$ hitung dengan $\mathrm{F}$ tabel. Jika $\mathrm{F}$ hitung terbesar kecil dari $\mathrm{F}$ tabel Kolmogorov smirnov, maka Ho diterima ; Ha ditolak. Jika nilai $\mathrm{F}$ hitung terbesar lebih besar dari $F$ tabel Kolmogorov smirnov. Maka Ho ditolak ; Ha diterima

Uji normalitas bertujuan untuk menguji apakah dalam model regresi, variabel pengganggu atau residual memiliki distribusi normal. Seperti diketahui bahwa uji $t$ dan $F$ mengasumsikan bahwa nilai residual mengikuti distribusi normal. Kalau asumsi ini dilanggar maka uji statistik menjadi tidak valid untuk jumlah sampel kecil (Ghozali, 2007:110). Menurut Ghozali, 2007 untuk mendeteksi uji normalitas dapat dilakukan melalui Analisa grafik. Analisa grafik ini dapat digunakan untuk menentukan normalitas dengan melihat grafik histogram yang membandingkan antara data observasi dengan distribusi yang mendekati distribusi normal.

Berdasarkan grafik dan test normality tersebut, terlihat bahwa data observasi terdistribusi dengan normal dimana kurvanya adalah normal. Oleh karena itu uji normalitas terpenuhi.

\section{Uji Linieritas}

Uji Linieritas adalah untuk mengetahui apakah model linier dapat digunakan untuk memprediksi besarnya sumbangan variabel bebas terhadap variabel terikat. Teknik yang digunakan adalah analisis uji-F dengan bantuan SPSS V16.0, untuk mencari harga regresi 
menggunakan prosedur Analyze $\rightarrow$ Regression $\rightarrow$ Linear.

\section{Uji Multikolinearitas}

Hal ini terbukti dengan didapatkannya nilai tolerence untuk semua variabel bebas berada diatas 0,10. Seperti nilai tolerence variabel Prilaku Kepemimpinan (X.1) sebesar 0,469 (VIF 2,130) dan untuk nilai variabel bebas kedua Iklim Organisasi( X.2) yaitu sebesar 0,451 ( VIF 2,220) dan nilai variabel bebas ketiga Disiplin Kerja (X3) sebesar 0,297 (VIF 3,364). Begitu juga jika dilihat dari nilai VIF (variance inflation factor), hanya satu dari variabel bebas memiliki nilai dibawah VIF diatas 10 yakni variable Disiplin Kerja (X3), sebagimana yang menjadi prasyarat untuk uji multikolonieritas.

1. Nilai Konstanta adalah 3,814 , berarti adanya faktor bebas yaitu Prilaku Kepemimpinan (X1), Iklim Organisasi (X2) dan Disiplin Kerja (X3) nilai dari factor terikat terhadap Kinerja (Y) naik sebesar 3,814 dengan asumsi faktor yang lain adalah tetap.

2. Nilai koefisien regresi dari faktor Prilaku Kepemimpinan (X1) adalah 0,013 mengandung arti jika nilai faktor Prilaku Kepemimpinan (X1) ditingkatkan sebesar satu satuan maka akan menyebabkan peningkatan nilai dari faktor terikat yaitu Kinerja (Y) sebesar 0,013 satuan dengan asumsi bahwa nilai dari faktor bebas yang lain adalah konstan atau nol.

3. Nilai koefisien regresi dari factor Iklim Organisasi (X2) adalah 0,174 mengandung arti jika nilai factor Iklim Organisasi (X2) ditingkatkan sebesar satu satuan maka akan menyebabkan peningkatan nilai dari faktor terikat yaitu Kinerja sebesar 0,174 satuan. dengan asumsi bahwa nilai dari factor bebas yang lain adalah konstan atau nol.

4. Nilai koefisien regresi dari faktor Disiplin Kerja (X3) adalah 0,307 mengandung arti jika nilai faktor
Disiplin Kerja (X3) ditingkatkan sebesar satu satuan maka akan menyebabkan penurunan nilai dari faktor terikat yaitu Kinerja sebesar 0,307 satuan. dengan asumsi bahwa nilai dari factor bebas yang lain adalah konstan atau nol.

\section{Uji Heterokedasitisitas}

Heterokedastisitas

dalam penelitian di uji dengan metode korelaso rank spearman antara nilai residual (error) hasil regresi dengan masing-masing variabel independen. apabila nilai korelasi spearman $\alpha$ maka pada model tidak terjadi gejala heterokedastisitas.

Berdasarkan semua nilai probabilitas dari variabel independen $>\alpha$, sehingga pelangaran asumsi klasik heteroskedastisitas dalam penelitian ini tidak terbukti.

\section{Pengujian hipotesis}

Uji F

Untuk menguji pengaruh variabel bebas terhadap variabel terikat maka digunakan ujii F. Untuk test hipotesis penelitian secara simultan dari variabel $\mathrm{X} 1$ terhadap $\mathrm{Y}$ digunakan uji $\mathrm{F}$ (pengujian secara keseluruhan) dengan prosedur sebagai berikut:

1. Apabila $\mathrm{F}$ hitung $>\mathrm{F}$ tabel, maka Ho ditolak dan Hi diterima, berarti ada pengaruh antara variabel bebas dengan variabel terikat.

2. Apabila Fhitung $\leq$ Ftabel, maka Ho diterima dan Hi ditolak, berarti variabel bebas tidak berpengaruh terhadap variabel terikat.

Sesuai dengan hasil perhitungan Uji $F$ yang dilakukan dengan bantuan program SPSS diperoleh nilai $\mathrm{F}$ hitung sebesar 1,355. Nilai signifikansi yang diperoleh adalah sebesar 0.000 , nilai signifikansi ini lebih kecil dari pada nilai (yaitu 0,05). Dengan demikian dapat diartikan bahwa faktor bebas yaitu Prilaku Kepemimpinan (X1), Iklim Organisasi (X2) dan Disiplin Kerja (X3) secara bersama berpengaruh terhadap faktor terikat yaitu Kinerja (Y). 
Berdasarkan hasil perhitungan nilai $F_{\text {hitung }}$ sebesar 1,355 sedangkan $F_{\text {tabel. }}$. pada $\alpha=5 \%, \mathrm{df}_{1}=5$, dan $\mathrm{df}_{2}=32$ sebesar 3,29; hal ini berarti $F_{\text {hitung }}>F_{\text {tabel }}$ $(13,5>3,29)$ sedangkan nilai probalitasnya lebih kecik dari $\alpha=0,05$ $(0,000<0.05)$, maka Ho ditolak dan $\mathrm{Hi}$ diterima, berarti ada pengaruh antara variabel bebas dengan variabel terikat yaitu variabel Prilaku Kepemimpinan (X1), Iklim Organisasi(X2) dan Disiplin Kerja (X3), secara simultan berpengaruh signifikan terhadap Kinerja (Y). Prilaku Kepemimpinan berpengaruh secara signifikan terhadap Kinerja (H1), Iklim Organisasiberpengaruh secara signifikan terhadap Kinerja (H2) dan Disiplin Kerja berpengaruh secara signifikan terhadap Kinerja (H3)

\section{Uji t}

Setelah diperoleh nilai $\mathrm{t}$ hitung selanjutnya dibandingkan dengan nilai $\mathrm{t}$ tabel, jika $\mathrm{t}$ hitung $>\mathrm{t}$ tabel maka koefisien jalurnya signifikan. Pengolahan data statistik tersebut di atas dilakukan dengan bantuan program SPSS.V16 Perbandingan $t_{\text {hitung }}$ dan $t_{\text {tabel }}$ $\alpha=5 \%$

\section{Analisis statistik Berganda}

Analisis regresi berganda digunakan untuk mengetahui besarnya pengaruh variabel $\left(\mathrm{X}_{1}\right)$, Variabel $\left(\mathrm{X}_{2}\right)$, Variabel $\left(\mathrm{X}_{3}\right)$, terhadap Variabel $(\mathrm{Y})$.

Hasil perhitungan regresi linier berganda, maka dapat dijelaskan sebagai berikut :

@ = 0,3814 menyatakan bahwa jika tidak ada perubahan variabel Prilaku Kepemimpinan $\quad\left(\mathrm{X}_{1}\right), \quad$ Iklim Organisasi $\left(\mathrm{X}_{2}\right)$, Disiplin Kerja $\left(\mathrm{X}_{3}\right)$, maka Kinerja (Y) sudah ada sebesar 38,14

$\beta_{1}=$ Koefisien regresi Prilaku Kepemimpinan $\left(\mathrm{X}_{1}\right)$ sebesar 0,013, menunjukkan besarnya pengaruh Prilaku Kepemimpinan $\left(\mathrm{X}_{1}\right)$ terhadap Kinerja (Y), Koefisien bertanda negatif menunjukan Prilaku Kepemimpinan $\left(\mathrm{X}_{1}\right)$ tidak berpengaruh searah terhadap
Kinerja (Y), yang berarti setiap kenaikan 1 satuan variabel $\left(\mathrm{X}_{1}\right)$ akan menyebabkan pengaruh terhadap Kinerja (Y) sebesar 0,013 dengan asumsi variabel Iklim Organisasi $\left(\mathrm{X}_{2}\right)$, Disiplin Kerja $\left(\mathrm{X}_{3}\right)$, besarnya konstan atau $1,3 \%$

$\beta_{2}=$ Koefisien regresi Iklim Organisasi $\left(\mathrm{X}_{2}\right) \quad$ sebesar $\quad 0,174$ menunjukan besarnya pengaruh Iklim Organisasi $\left(\mathrm{X}_{2}\right)$ terhadap Kinerja (Y), Koefisien bertanda negatif menunjukan Iklim Organisasi $\left(\mathrm{X}_{2}\right)$ tidak berpengaruh searah terhadap Kinerja (Y), yang berarti setiap kenaikan 1 satuan variabel Iklim Organisasi $\left(\mathrm{X}_{2}\right)$ akan menyebabkan pengaruh terhadap Kinerja (Y) sebesar 0,283; dengan asumsi variabel Prilaku Kepemimpinan $\left(\mathrm{X}_{1}\right)$, Disiplin Kerja $\left(\mathrm{X}_{3}\right)$, besarnya konstant atau $17,4 \%$ $\beta_{3}=$ Koefisien regresi Disiplin Kerja $\left(X_{3}\right)$ sebesar 0,307 menunjukan kurangnya pengaruh Disiplin Kerja $\left(\mathrm{X}_{3}\right)$ terhadap Kinerja $(\mathrm{Y})$, Koefisien bertanda Negatif menunjukan Disiplin Kerja $\left(\mathrm{X}_{3}\right)$ tidak berpengaruh searah terhadap Kinerja (Y), yang berarti setiap kenaikan 1 satuan variabel Disiplin Kerja $\left(\mathrm{X}_{3}\right)$ tidak ada pengaruh terhadap Kinerja (Y) sebesar 0,307; dengan asumsi variabel Prilaku Kepemimpinan $\quad\left(\mathrm{X}_{1}\right)$, Iklim Organisasi $\left(\mathrm{X}_{2}\right)$, besarnya konstant atau $30,7 \%$.

Koefisien korelasi berganda (R) sebesar 0,356; menunjukan bahwa bersama-sama terdapat hubungan yang kuat dan searah antara variabel $\left(\mathrm{X}_{1}\right)$, Variabel $\left(\mathrm{X}_{2}\right)$, Variabel $\left(\mathrm{X}_{3}\right)$, terhadap Kinerja (Y) sebesar 35,6\%. Hubungan ini dapat di kategorika cukup kuat, sebagaimna diketahui bahwa suatu hubungan dikatakan sempurna jika koefisien korelasinya mencapai 100\% atau 1 (baik dengan angka positif atau negatif) 
Berdasarkan hasil analisis regresi diperoleh koefisiensi determinasi $\mathrm{R}$ Square sebesar $0,127 \%$. besarnya pengaruh variabel bebas terhadap variabel terikat sebesar 12,7 sedangkan sisanya sebesar 77,3 \% merupakan faktor lain yang tidak diteliti. Nilai koefisien determinasi tersebut menunjukkan kuatnya pengaruh variabel bebas secara bersama-sama terhadap variabel terikat.

\section{Pembahasan}

Dari hasil-hasil regresi berganda diperoleh nilai koefisien yang positif semua. Hal ini menunjukkan bahwa setiap kenaikan variabel $\mathrm{X}$ akan diikuti dengan kenaikan variabel Y. Pada hasil uji asumsi klasik diperoleh bahwa persamaan regresi sudah memenuhi asumsi klasik yaitu datanya normal, tidak terjadi multikolinieritas, tidak terjadi heteroskedastistas, dan tidak terjadi autokorelasi.

Pada korelasi nilai koefisien korelasi (R) ternyata bahwa korelasinya positif. Hal ini berarti bahwa ada hubungan yang kuat searah, dimana perubahan kenaikan yang terjadi pada faktor bebas yaitu Prilaku Kepemimpinan $\left(\mathrm{X}_{1}\right)$, Iklim Organisasi $\left(\mathrm{X}_{2}\right)$ dan Disiplin Kerja $\left(X_{3}\right)$ diiringi dengan perubahan kenaikan faktor terikat yaitu Kinerja Polresta Padang(Y).

Dari hasil penelitian diperoleh bahwa faktor Prilaku Kepemimpinan $\left(\mathrm{X}_{1}\right)$, merupakan faktor bebas yang dominan mempengaruhi faktor terikat yaitu Kinerja Polresta Padang (Y). Pada pengujian dengan uji $t$ maupun dengan uji F diketahui bahwa faktor bebas yaitu Prilaku Kepemimpinan $\left(\mathrm{X}_{1}\right)$, Iklim Organisasi $\left(\mathrm{X}_{2}\right)$ dan Disiplin Kerja $\left(\mathrm{X}_{3}\right)$ baik secara bersama berpengaruh terhadap faktor terikat yaitu Kinerja Polresta Padang(Y).

Hasil penelitian menunjukan dapat diketahui bahwa dari 32 responden yang diteliti secara umum menyatakan terhadap Prilaku Kepemimpinan $\left(\mathrm{X}_{1}\right)$ didapatkan nilai rata-rata skor 3,75 hal ini berarti rata rata responden menyatakan setuju Kinerja Polresta Padang(Y) dipengaruhi oleh Prilaku Kepemimpinan.

Hasil penelitian menunjukan dapat diketahui bahwa dari 32 responden yang diteliti secara umum menyatakan terhadap Iklim Organisasi(X2) didapatkan nilai rata-rata skor 4,29 hal ini berarti rata rata responden menyatakan setuju Kinerja Polresta Padang(Y) dipengaruhi Iklim Organisasi Kenyataan yang bisa dilihat dari Kinerja Polresta Padang tidak semua sesuai dengan tugas pokok mereka.

Hasil penelitian menunjukan dapat diketahui bahwa dari 32 responden yang diteliti secara umum menyatakan terhadap Disiplin Kerja (X3) didapatkan nilai ratarata skor 4,16 hal ini berarti rata rata responden menyatakan setuju Kinerja Polresta Padang(Y) dipengaruhi oleh Disiplin Kerja.

\section{Kesimpulan}

1. Hasil analisis regresi diperoleh nilai $\mathrm{t}_{\text {hitung }}=25,50$ sedangkan nilai $\mathrm{t}_{\text {tabel }}=$ 2,042 sehingga $t_{\text {hitung }}>t_{\text {tabel }}$ dan nilai signifikansinya adalah 0,000 , nilai ini lebih kecil daripada $\alpha=0,05$ sehingga dapat dikatakan bahwa faktor Prilaku Kepemimpinan (X1) berpengaruh signifikan terhadap Kinerja (Y) Polresta Padang

2. Hasil analisis regresi diperoleh nilai $\mathrm{t}_{\text {hitung }}=-1,076$ sedangkan nilai $\mathrm{t}_{\text {tabel }}=$ 2,042 sehingga $t_{\text {hitung }}<t_{\text {tabel }}$ atau dan nilai signifikansinya adalah 0,000 , nilai ini lebih kecil daripada $\alpha=0,05$, dan terbukti variabel Iklim Organisasi $\left(\mathrm{X}_{2}\right)$ berpengaruh tidak signifikan terhadap Kinerja (Y) Polresta Padang.

3. Hasil analisis regresi diperoleh nilai $\mathrm{t}_{\text {hitung }}=1,715$ sedangkan nilai $\mathrm{t}_{\text {tabel }}=$ 2,042 sehingga $t_{\text {hitung }}<t_{\text {tabel }}$ dan nilai signifikansinya adalah 0,000 , nilai ini lebih kecil daripada $\alpha=0,05$, dan terbukti variabel Disiplin Kerja $\left(\mathrm{X}_{3}\right)$ berpengaruh tidak signifikan terhadap Kinerja (Y) Polresta Padang

4. Nilai koefisien korelasi (R) ternyata 
bahwa korelasinya positif. Hal ini berarti bahwa ada hubungan yang kuat searah, dimana perubahan kenaikan yang terjadi pada faktor bebas yaitu Prilaku Kepemimpinan, Iklim Organisasi dan Disiplin Kerja diiringi dengan perubahan kenaikan faktor terikat yaitu Kinerja (Y) Polresta Padang.

\section{Saran}

Kepada Polresta Padang

Perlu meningkatkan Prilaku Kepemimpinan antara lain agar dapat lebih meningkatkan kemampuan mereka dalam melaksanakan tugas dengan lebih memberikan perhatian dan pelatihan terkait dengan Prilaku Kepemimpinan, Iklim Organisasi dan Disiplin Kerja, sehingga mereka bekerja dengan optimal, berintegritas dan bertanggung jawab.

\section{Kepada program studi magister manajemen program pasca sarjana STIE KBP Padang}

Dapat menjadikan bahan pengembangan ilmu pengetahuan dan teknologi manajemen, yang berkaitan dengan Prilaku Kepemimpinan, Iklim Organisasi dan Disiplin Kerja.

\section{Kepada peneliti}

a. Dapat dilakukan penelitian lebih lanjut dengan menghubungkan faktor faktor yang ada di variabel confounding.

b. Dapat dikembangkan dengan menambah faktor-faktor pada variabel independen yang dapat mempengaruhi variabel dependen.

\section{DAFTAR PUSTAKA}

Yudistira, D. S., \& Susanti, F. (2019). Pengaruh Motivasi Kerja Dan Budaya Kerja Terhadap Kinerja Karyawan Dinas Pemberdayaan Masyarakat Dan Desa, Pengendalian Penduduk Dan Keluarga Berencana Kabupaten Pesisir Selatan. https://doi.org/10.31227/osf.io/jk54m

Ridho, M., \& Susanti, F. (2019). Pengaruh Stres Kerja Dan Motivasi Kerja Terhadap Kepuasan Kerja Pada Karyawan Bank Mandiri Syariah Cabang Padang. https://doi.org/10.31227/osf.io/pa2cg

Lubis, A. Y. O., \& Susanti, F. (2019). Pengaruh Gaya Kepemimpinan Dan Kompensasi Terhadap Prestasi Kerja Karyawan (Studi pada PT Japfa Comfeed Indonesia (JCI) Tbk Devisi Fam 1. https://doi.org/10.31227/osf.io/7tbrg

Jamarnis, S., \& Susanti, F. (2019). Pengaruh Harga Dan Periklanan Melalui Internet Terhadap Keputusan Pembelian Produk Sabun Merek Lux Pada Mahasiswa STIE “KBP” Padang. https://doi.org/10.31227/osf.io/xz3d8

Aldi, Y., \& Susanti, F. (2019). Pengaruh Stress Kerja Dan Motivasi Kerja Terhadap Prestasi Kerja Karyawan Pada PT. Frisian Flag Indonesia Wilayah Padang. https://doi.org/10.31227/osf.io/et4rn

Widodo, B. H., \& Susanti, F. (2019). Pengaruh Human Relation (Hubungan Antar Manusia), Lingkungan kerja Terhadap Etos Kerja karyawan (Studi Kasus Pada PT. Pelindo Teluk Bayur Padang ). https://doi.org/10.31227/osf.io/dxm8a

Junaidi, R., \& Susanti, F. (2019). Pengaruh Gaya Kepemimpinan Dan Budaya Organisasi Terhadap Kinerja Pegawai Pada UPTD Baltekkomdik Dinas 
Pendidikan Provinsi Sumatera Barat. https://doi.org/10.31227/osf.io/bzq75

Selamat, S. Heryanto, H. (2019). Affecting Factors In Employee Performance Koto Baru Sub-District, Dharmasraya District. Archives of Business Research 7 (7), 142-154

Ermayenti, E. Heryanto, H. (2019). The Effect Of Competence And Discipline Of Work On Public Satisfaction In The Regional Office Of The Ministry Of Religion In West Sumatera Province With Quality Of Service As An Intervening Variable. Archives of Business Research 7 (7), 69-87

Kurniawan, H. Heryanto, H. (2019). Effect of Work Discipline and Work Environment on Employee Performance with Work Motivation as an Intervening Variable in Department of Tourism, Youth and Sport of Padang District. Archives of Business Research 7 (7), 88-101

Sari, N. Heryanto, H. (2019). The Effect Of Training And Utilization Of SIPKD On Competency And Its Impact On The Quality Of Financial Statements In Dharmasraya Regency SKPD. Archives of Business Research 7 (7), 112-121

Fatra, A. Heryanto, A. (2019). The Effect Of Implementation Of Population Administration Policy And Employee Motivation On Quality Of Service And Its Impact On Community Satisfaction In Issuance Of Birth ACCESS (Case in: The Department of Population and Civil Registration of the Dharmasraya Regency). Archives of Business Research 7 (7), 155-165

Yusrisal, Y. Heryanto, H.( 2019). The Influence of Leadership and Competence on Work Motivation and its impact on Employee Performance at the Koto Besar Sub-District Office, Dharmasraya Regency. Archives of Business Research 7 (7), 122-131

Syukri, M. Heryanto, H. (2019). The Influence Of Leadership Style, And Organizational Commitment, On Employee Discipline And Also Its Impact On Employee Performance Of The Dharmasraya District Community And Village Empowerment Office. Archives of Business Research 7 (7), 102111

Septria, D. Heryanto, H. (2019). Performance Capability Analysis and Regional Budget Evaluation in Implementing Regional Autonomy in Dharmasraya District. Archives of Business Research 7 (7), 180-187

Meldi, M. Heryanto, H. (2019). The Influence Of Quality Of Human Resources And Communication On The Performance Of Civil Servants In The Regional Secretariat Of Dharmasraya Regency With Organizational Commitment As Intervening Variables. Archives of Business Research 7 (7), 132-141

Wahyuni, N. Heryanto, H. (2019). The Effect of Environment and Motivation on Employee Performance with Organizational Culture as an intervening variable on Bank Perkreditan Rakyat Jorong Kampung Tangah Pariaman PT. Archives 
of Business Research 7 (5)

Khamri, A. Heryanto, H. (2019). The Influence of the Work Environment, Work Discipline on the Spirit of Work and Its Impact on Employee Performance at the Dharmasraya District Health Office. Archives of Business Research 7 (5)

Irvan, RM. Heryanto, H. (2019). The Effect of Competence and Workload on Motivation and Its Impact on the Performance of Civil Servants at the Regional Secretariat of the Regency of Dharmasraya. Archives of Business Research 7 (5)

Jamilus, J. Heryanto, H. (2019). The Effect of Competence, Communication \& Motivation on Employee Performance in People's Welfare Regional Secretariat of Padang City, Indonesia. Archives of Business Research 7 (5)

Zukriah, A. Heryanto, H. (2019). The Effect Of Work Motivation And Discipline On Employee Performance In Human Resources Development Agency, West Sumatera With Education And Training As Variable Intervening. Archives of Business Research 7 (5)

Marunduri, P. Heryanto, H. (2019). Analysis of the Effect of Training and Motivation on Organizational Commitments and Its Impact on Employee Performance (Study on Insurance Marketing Agents on Prudential Agency Pru-Aini Gunung Sitoli PT). Archives of Business Research 7 (5)

Syamsudirman, S. Yurmain, H. Heryanto, H. (2019). Compensation and Work Culture on Organizational Performance with in mediation by Work Satisfaction in Fire Department Service of Sungai Penuh City. Archives of Business Research 7 (2)

Heryanto, H. (2019). The Effect of Work Motivation and Work Environment on Performance With Satisfaction as Intervening Variables Education Personnel Rektorate Andalas University. Archives of Business Research 7 (2)

Heryanto, H. Sumarni, S. (2019). The Effect of Certification, Competence, and Motivation on Teachers Performance of Country Civil Apparatus in Sawahlunto City. Archives of Business Research 7 (1)

Eliza, Y. (2015). Pengaruh moralitas individu dan pengendalian internal terhadap kecenderungan kecurangan akuntansi (Studi Empiris Pada SKPD di Kota Padang). Jurnal Akuntansi (Media Riset Akuntansi \& Keuangan) 4 (1), 86-100

Eliza, Y. (2015). Pengaruh Investasi, Angkatan Kerja dan Pengeluaran Pemerintah terhadap Pertumbuhan Ekonomi di Sumatera Barat. PEKBIS (Jurnal Pendidikan Ekonomi Dan Bisnis) 7 (3), 198-208

Eliza, Y. Adriani, E. Maryanti, S. (2019). The Analysis Return on Investment Education of Married Woman in Indonesia. KnE Social Sciences, 667-688$667-688$ 
Maryanti, S. Eliza, Y. Wiyati, R. Thamrin, M. (2018). The Growth of the Population: Labor Potential Mapping in Pekanbaru Indonesia. IOP Conference Series: Earth and Environmental Science 175 (1), 012092

Eliza, Y. (2015). Analisis Kepuasan Masyarakat Atas Kualitas Pelayanan Kantor Kecamatan Siberut Selatan Kabupaten Kepulauan Mentawai. Jurnal Pendidikan Ekonomi dan Bisnis 7 (1), 65-75

Yuharmain, H. Suryana, Y. Novianty, R, Joeliaty. (2016). An Impact Study Of Rural Credit Bank Existence Towards Micro And Small Businesses In Padang City. International Journal Of Scientific \& Technology Research 5 (7), 145-150

Edasa, D. Putra, EE. (2015). Pengaruh Gaya Kepemimpinan, Lingkungan Kerja dan Motivasi Kerja Terhadap Kinerja Pegawai LPP-RRI Bukittinggi. Jurnal Riset Manajemen Bisnis dan Publik 3 (2)

Putra, EE. (2015). Keadilan Dalam Organisasi. Buletin Organisasi dan Aparatur

Putra, EE. (2015). Pentingnya ISO Bagi Lembaga Pendidikan Dan Latihan. Buletin Badan Diklat Prov. Sumatera Barat

Putra, EE. (2015). Urgensi Pengembangan Potensi Aparatur Sipil Negara (ASN). Buletin Badan Diklat Prov. Sumatera Barat

Putra, EE. (2014). The Effect of Human Capital, Structural and Customer Capital to Performance of Small Medium Enterprises at West Sumatera Province. Business Administration at Jose Rizal University

Putra, RY. Marlius, D. (2019). Pengaruh Pendidikan, Pengalaman Kerja dan Etos Kerja Terhadap Kinerja Pegawai Di KPN Batur. Academic Conference For Management 2.

Marlius, D. RD Putra. (2018). Strategi Pengembangan Sulam Bayang. Jurnal Benefita: Ekonomi Pembangunan Manajemen Bisnis Dan Akuntansi. Volume 3. No. 2. Hal. 204-218. http://doi.org/10.22216/jbe.v3i2.3494 